\title{
CDK5 Regulatory Subunit-Associated Protein 3
}

National Cancer Institute

\section{Source}

National Cancer Institute. CDK5 Regulatory Subunit-Associated Protein 3. NCI

Thesaurus. Code C71454.

CDK5 regulatory subunit-associated protein 3 (506 aa, $\sim 57 \mathrm{kDa}$ ) is encoded by the human CDK5RAP3 gene. This protein plays a role in the regulation of the cell cycle and cellular proliferation. 